\title{
Glacial land forms indicative of a partly frozen bed
}

\author{
JOHAN KLEMAN AND INGMAR BORGSTRÖM \\ Department of Physical Geography, Stockholm University, S-106 91 Stockholm, Sweden
}

\begin{abstract}
In parts of the core area of the Fennoscandian ice sheet relict periglacial surfaces occur. The boundary between periglacial and glacial landscapes is often sharp and erosional, with fluting truncating patterned ground. The periglacial surfaces are older than the last ice sheet and are interpreted to represent patches of continuous frozen-bed conditions. A specific land-form assemblage occurs at the edges of such patches. On the basis of three type localities along the eastern rim of the Scandinavian mountains, four thermal boundary land forms, characteristic of the frozen-patch environment, are defined. Stoss-side moraines and transverse till scarps, not previously described, are interpreted to have formed in detachment zones where soil frozen to the glacier overlies thawed soil. The detachment zones are located where subglacial warming raises the phase-change surface (water/ice) until it intersects the soil layer up- and down-glacier from residual frozen-bed patches. The up-glacier ends of frozen-bed patches are located on topographic highs, but downglacier the location of lateral sliding boundaries is occasionally independent of topography. The identification of relict surfaces and thermal boundary forms can improve paleo-ice-sheet models by providing estimates of the extent of frozen-bed conditions.
\end{abstract}

\section{INTRODUGTION}

In the following we describe an assemblage of subglacial land forms that we interpret to have formed at the edges of frozen-bed patches. These patches provide information about the distribution of frozen-bed and thawed-bed areas beneath parts of the last Fennoscandian ice sheet. Ice-sheet models usually depict broad thermal zones, either arranged concentrically (Sugden, 1978; Denton and Hughes, 1981) or topographically, or substratum controlled (Fastook and Holmlund, 1994). One of the striking features of glacial morphology maps (Prest and others, 1968; Sollid and Kristiansen, 1982; Borgström, 1989) is, however, the "patchiness" of the glacial bedform distribution in former core areas of ice sheets. Fields of distinctly different bed forms often occur in radially arranged fans, suggesting important differences, transverse to flow lines, in the subglacial environment.

Observational or geological evidence for basal thermal patterns has been available principally at the "very small" and "very large" ends of the continuum of spatial scales. Freezing-thawing patterns at the size of individual roches moutonnées have been observed (Carol, 1947; Goodman and others, 1979) and evidence also exists for basal thermal patterns on the scale of large paleo-ice streams (10-200 km) (Dyke and Morris, 1988). However, few instances of intermediate-scale basal thermal patterns in the low- to medium-relief terrain that areally dominated the Scandinavian and Laurentide ice sheets have been described.

Here we deal with a special subglacial land-form assemblage occurring on the $1-10 \mathrm{~km}$ scale. These patches occur on low uplands with a completely preserved periglacial landscape of pre-late Weichselian age, surrounded by late Weichselian fluting. Locations are shown in Figure 1. The boundary between the periglacial

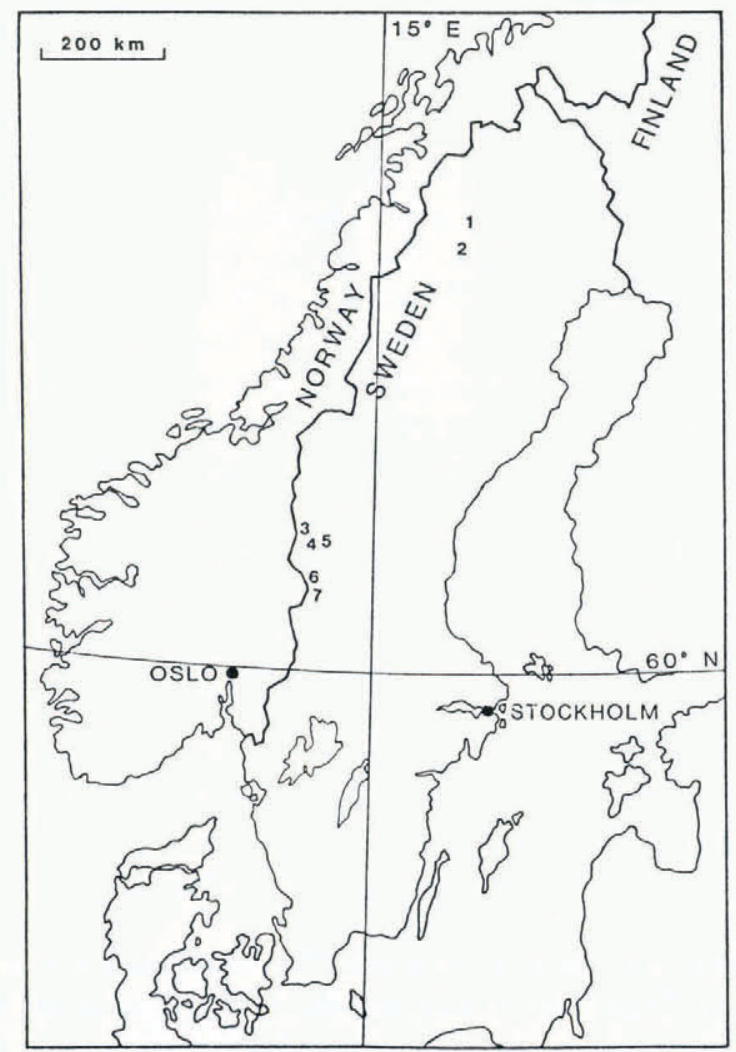

Fig. 1. Location map. Numbers show location of sites mentioned in text. 1, Tjuolma; 2, Arvestuottar; 3, Långfjället; 4, Städjan; 5, Häggingfjället; 6, Fulufjället; 7, Transtrand. 


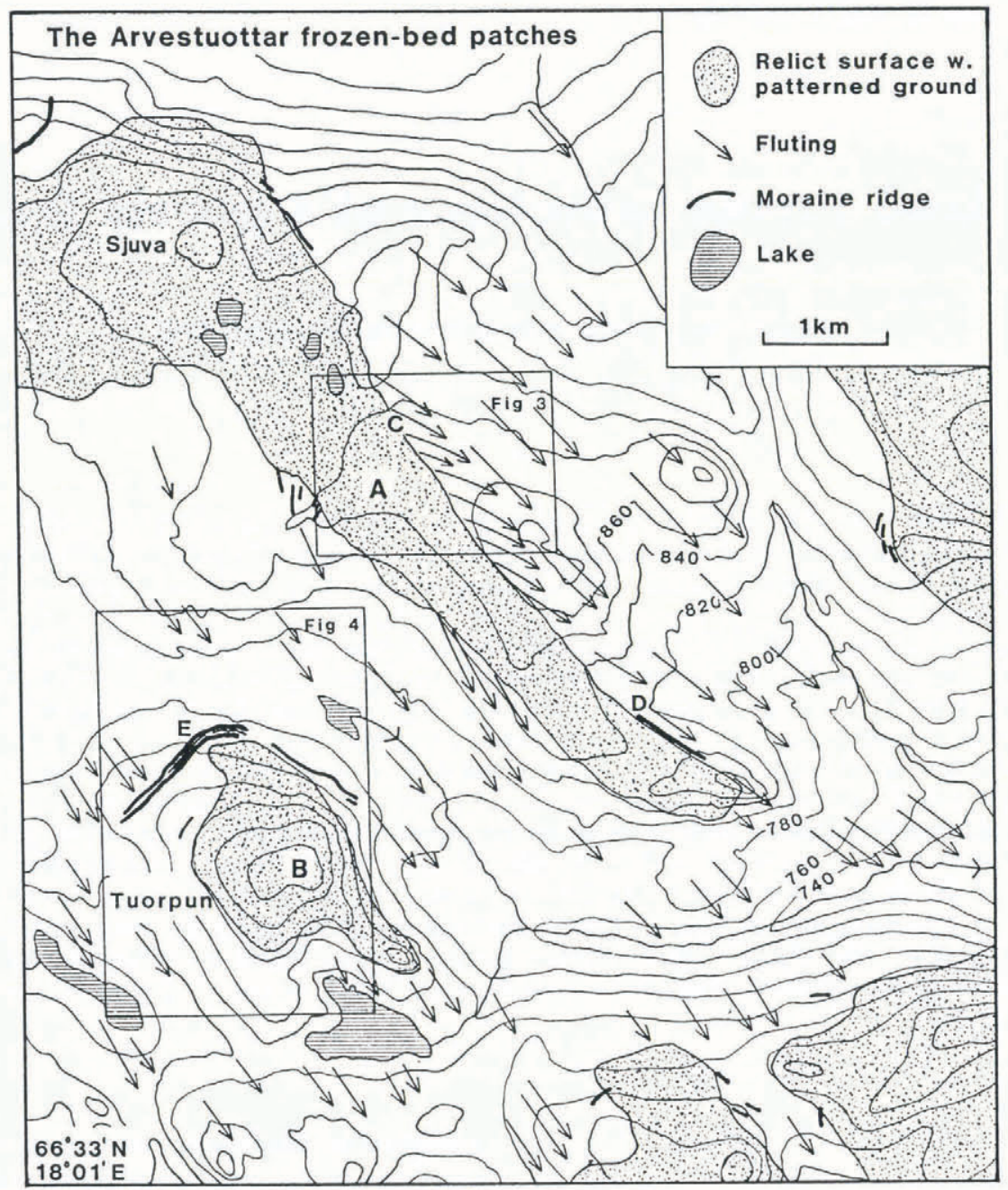

Fig. 2. Map of the Arvestuottar area. The relict surfaces $(A, B)$, marking the sites of former frozen-bed patches, are located on topographic highs and are elongated in the ice-flow direction. Boxes show locations of Figures 3 and 4 . Moraine ridges $(D, E)$ occur proximally and laterally to the relict surfaces.

and glacial landscapes is often sharp and erosional, as where fluting truncates patterned ground (Figs 2 and 3 ), and can only be explained as the result of glacial erosion after the formation of the periglacial landscape (Kleman and Borgström, 1990). We therefore have remnants of a ground surface that have survived fully intact beneath an ice sheet. In all probability, the survival of these relict surfaces results from uninterrupted frozen-bed conditions (Lagerbäck, 1988b; Kleman and Borgström, 1990; Kleman, 1992). Field evidence for preservation of landscapes and land forms under cold-based parts of ice sheets has also been reported from the Laurentide area (Sugden and Watts, 1977; Dyke, 1983; Dyke and others, 1992). In the following the term "relict surface" is used for a surface that was ice-covered but not modified, regardless of whether it is a subaerially formed surface or a glacially sculpted surface from an older flow phase. Hence, relict surfaces are taken to represent former frozen-bed areas.

The last glaciation in central Scandinavia was during the late Weichselian. The minimum duration of the last ice cover was around $20 \mathrm{ka}$ but the actual length was more probably $50 \mathrm{ka}$ (Andersen and Mangerud, 1989). The glacial history of west-central Sweden has been discussed by Borgström (1989), Kleman and Borgström (1990), Kleman (1990) and Kleman and others (1992).
Accounts of the glacial history of northern Sweden have been given by Lagerbäck (1988a,b), Lagerbäck and Robertsson (1988) and Kleman (1992). In both areas, land forms from late stages of the last stadial are overprinted on abundant (northern Sweden) or scattered (west-central Sweden) land forms from previous ice sheets. At the three localities we have studied, the last deglaciation occurred during the time interval 10000 $9000 \mathrm{BP}$; deglaciation was continuous and rapid, without any signs of halts or re-advances (Kleman, 1990, 1992; Lundqvist, 1992).

\section{LOGALITIES}

The most clearly delineated frozen-bed "patches" yet located in Sweden are at Avestuottar, Häggingfjället and Fulufjället. All three are located on undulating uplands at $800-1000 \mathrm{~m}$ a.s.l. In the following paragraphs we will describe the salient features of each locality.

\section{Arvestuottar}

Patch $\mathrm{A}$ in Figure 2 is a striking patterned-ground area devoid of any glacial land forms. It is aligned with the last recorded ice-flow direction. The lateral borders of the 


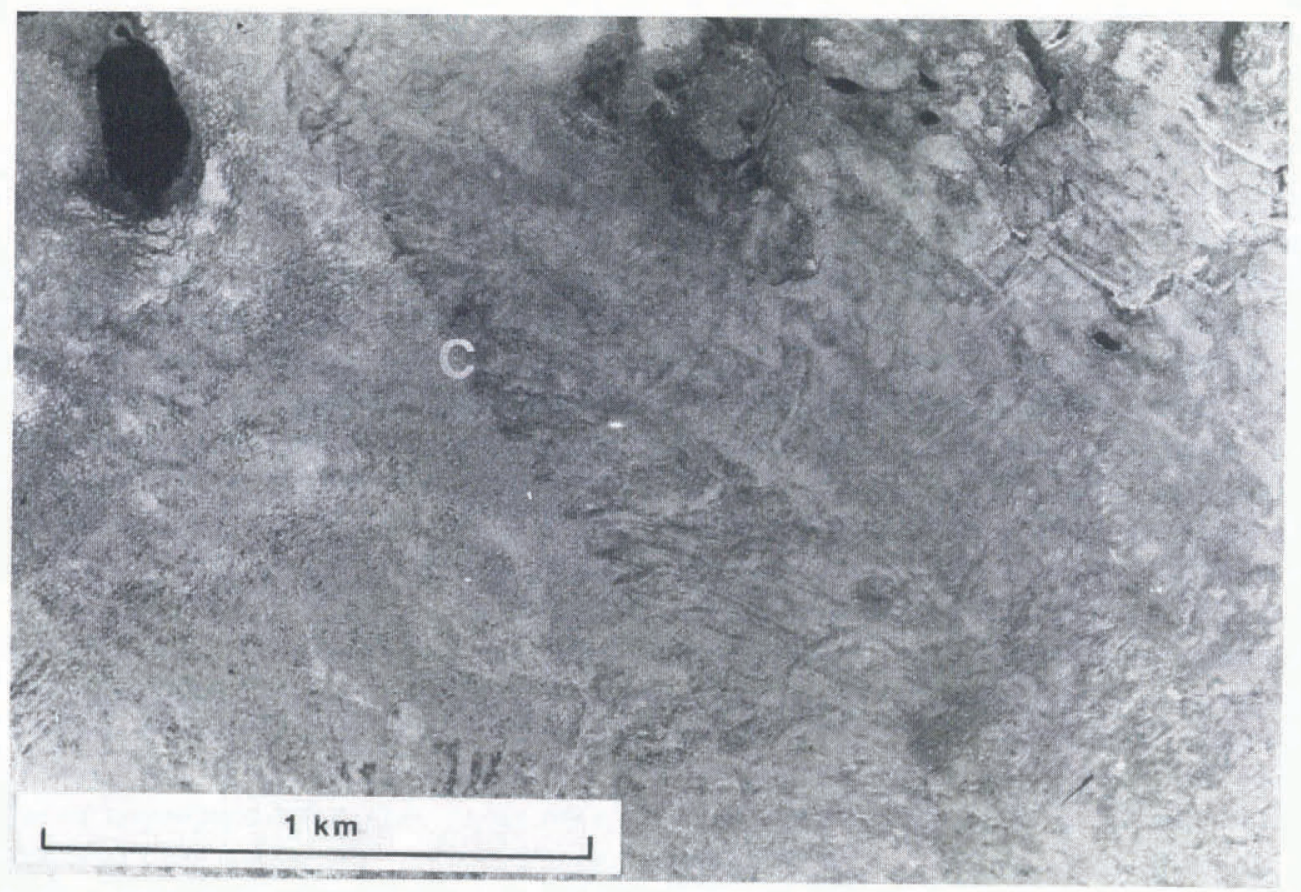

Fig. 3. Vertical aerial photograph of a lateral sliding boundary (C) at Arvestuottar. The area to the left of the boundary bears patterned ground and lacks glacial flow features. It is interpreted as a relict (interstadial) surface, preserved by continuous frozen-bed conditions. The area to the right is fluted and lacks patterned ground.

patch ( $\mathrm{C}$ in Figures 2 and 3) are sharp and hence erosional. At $\mathrm{C}$, the full change from a patterned-ground surface to a fluted surface occurs within less than $20 \mathrm{~m}$. The northeastern boundary of patch A first rises in the direction of flow, then decreases in elevation, and then rises again, resulting in what we call an up-down-up profile. Trim lines around nunataks should be expected to descend monotonously in the down-glacier direction and

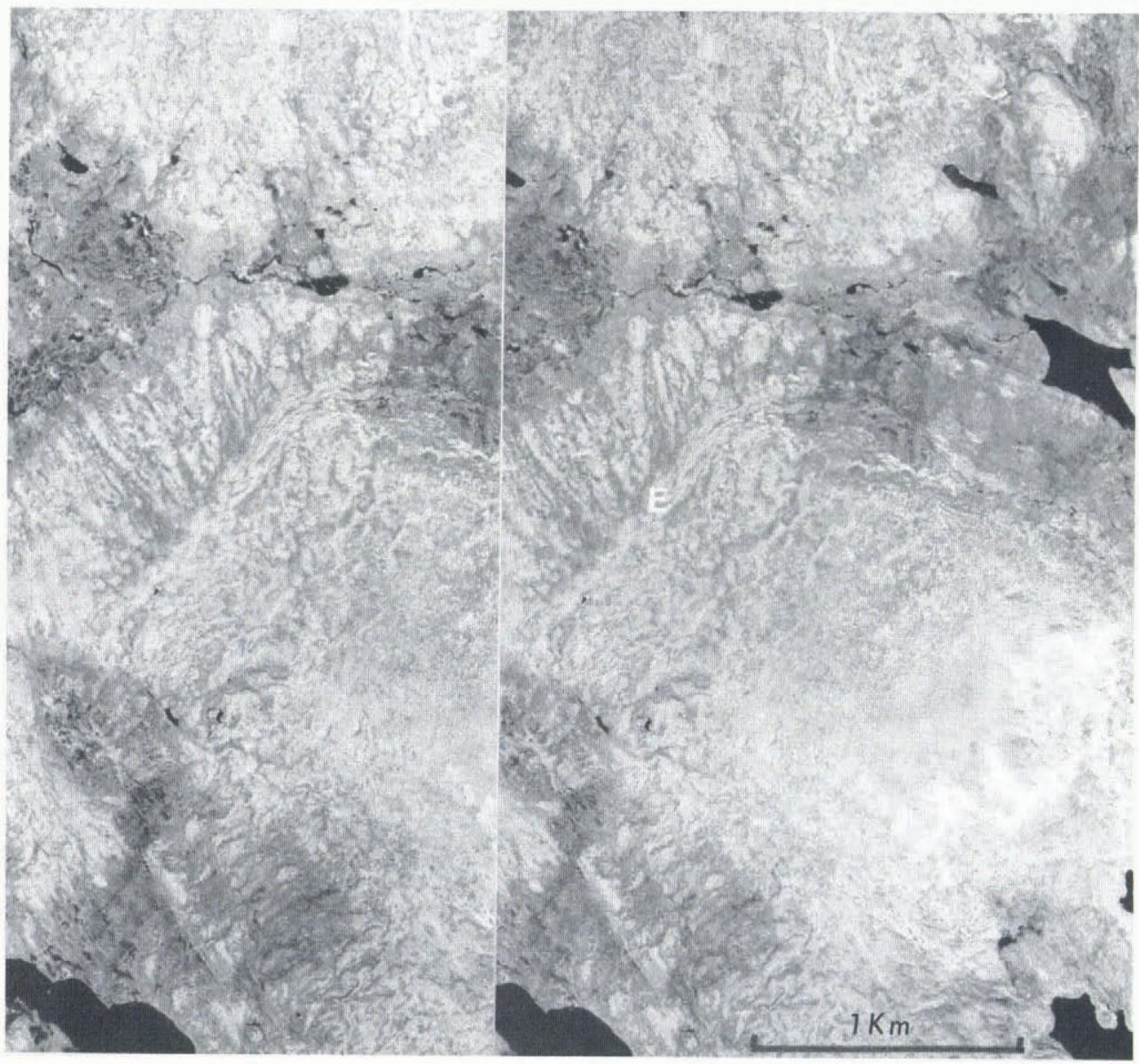

Fig. 4. Stereogram of the stoss-side ridge (E) at Tourpun, Arvestuottar. The ridge is located a short distance up-glacier from a relict surface. See Figure 2 for location. 
we therefore consider these profiles to reflect subglacial boundaries. The sharp erosional contacts are interpreted as marking the limit between thawed bed and frozen bed. Similar sharp contacts between fluted till and polygonized relict surfaces have also been identified at Långfjället, Städjan, Fulufjället and Tjuolma (Kleman, 1992), and have been referred to as "lateral sliding boundaries" (Dyke and Morris, 1988).

The upstream end of patch A rests on Sjuva, a rounded hill. The patch extends as a ribbon down-flow from this summit. The central part of the patch lies on a valley slope. Therefore, although topography exerted broad control in fixing the position of the stoss end of the patch, its sides were determined by the ice-flow pattern, not by breaks in slope, and hence not by changes in ice thickness. Basal sliding has occurred on adjacent higher as well as lower ground.

At some distance from the boundary, the fluting direction conforms with the general fluting direction over the map area. However, along the central part of patch A, the fluting direction close to the margins deviates considerably from the regional fluting direction. If these flutes formed in strict alignment to the flow direction, which is generally to be assumed, then the flow of basal ice leaving the patch was clearly divergent, by about $10^{\circ}$. Where fluting indicates basal flow obliquely out of the patch, a low step separates the higher relict surface from the lower fluted surface. The same relationship has been found at Långfjället.

The distal part of the northeast lateral boundary is formed by a $600 \mathrm{~m}$ till ridge (D in Fig. 2). This ridge is in a location similar to that of the drumlin-field boundary ridge (lateral shear moraine) described by Dyke and
Morris (1988). Ridge D is located on a section of the lateral sliding boundary where fluting points slightly into the preserved patch. Thus, there are indications that flow obliquely into the patch led to accumulation of debris while flow obliquely out of the patch was associated with erosion.

At Tuorpun (E, Figs 2 and 4) a transverse moraine ridge occurs directly up-glacier from patch $\mathrm{B}$. Its northeastern part is multi-crested and is concave down-glacier. Similar stoss-side ridges occur on other hills near the map area. A transverse ridge in a similar location relative to a relict surface is found in the upper left corner of Figure 2.

\section{Häggingfjället}

Häggingfjället is a gently rounded mountain with two summits (Fig. 5). Local relief (within $5 \mathrm{~km}$ ) is about $400 \mathrm{~m}$, whereas regional relief is about $600 \mathrm{~m}$. Although the two summits (A and B in Figures 5 and 6 ) are only $1 \mathrm{~km}$ apart, they differ completely in the morphology of their soil cover. The higher western summit (B) is entirely fluted, has several fields of large glacially transported boulders (boulder blanket; see Kleman and Borgström, 1990) drawn out along-flow and lacks patterned ground. The eastern summit is partly fluted but also has a large area (C, Figs 5 and 6 ) characterized by stone stripes and sorted polygons. The margins of this periglacial area are erosional, but the sides and proximal edge are not as sharp as at Arvestuottar and Fulufjället; the transition from polygonized surface to fluted till occurs over a distance of about $100 \mathrm{~m}$.

Periglacial area $\mathrm{C}$ ends abruptly down-glacier at a 3$15 \mathrm{~m}$ high till scarp that descends to bare bedrock. The

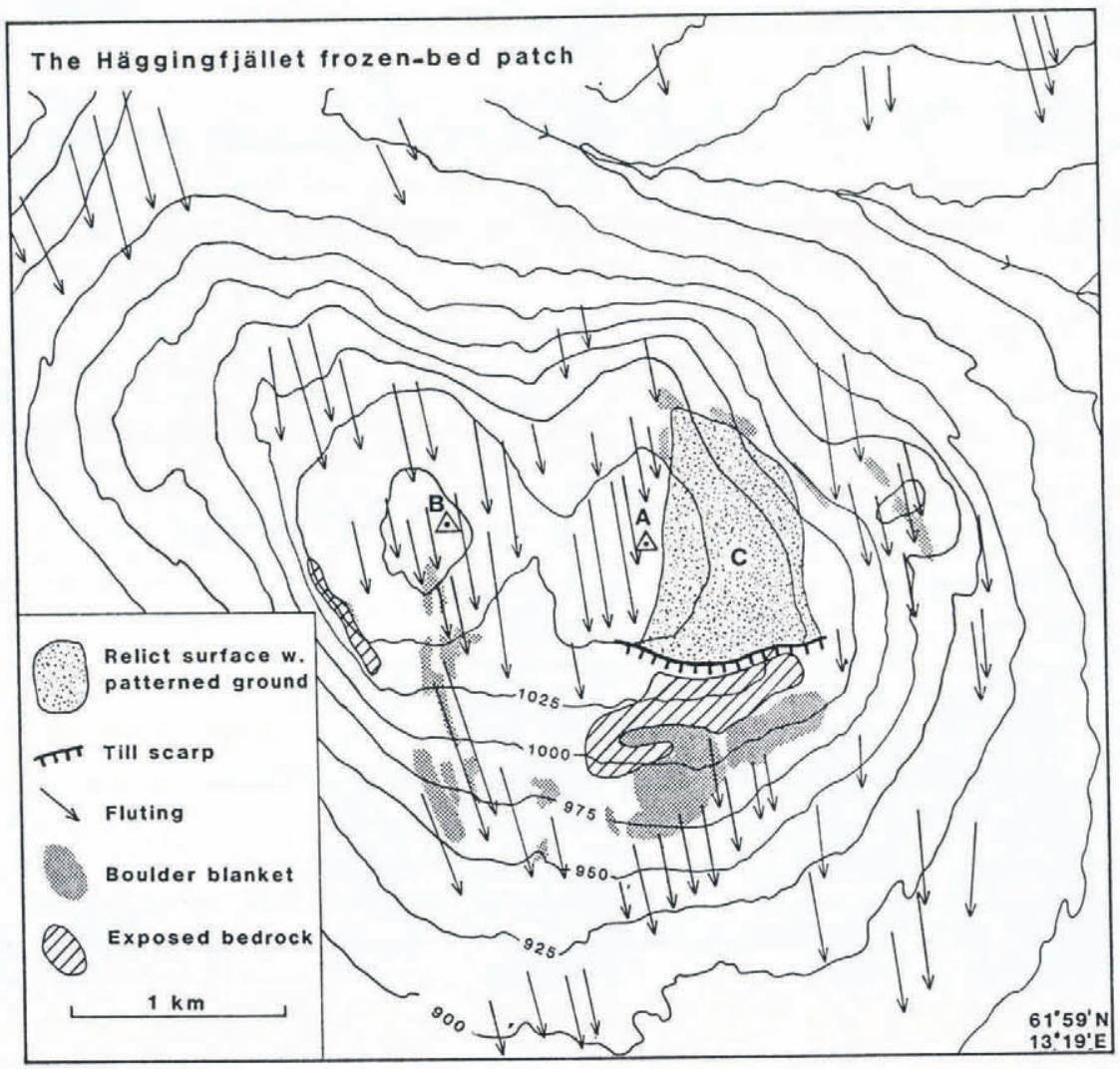

Fig. 5. Map of the Häggingfjället area. 


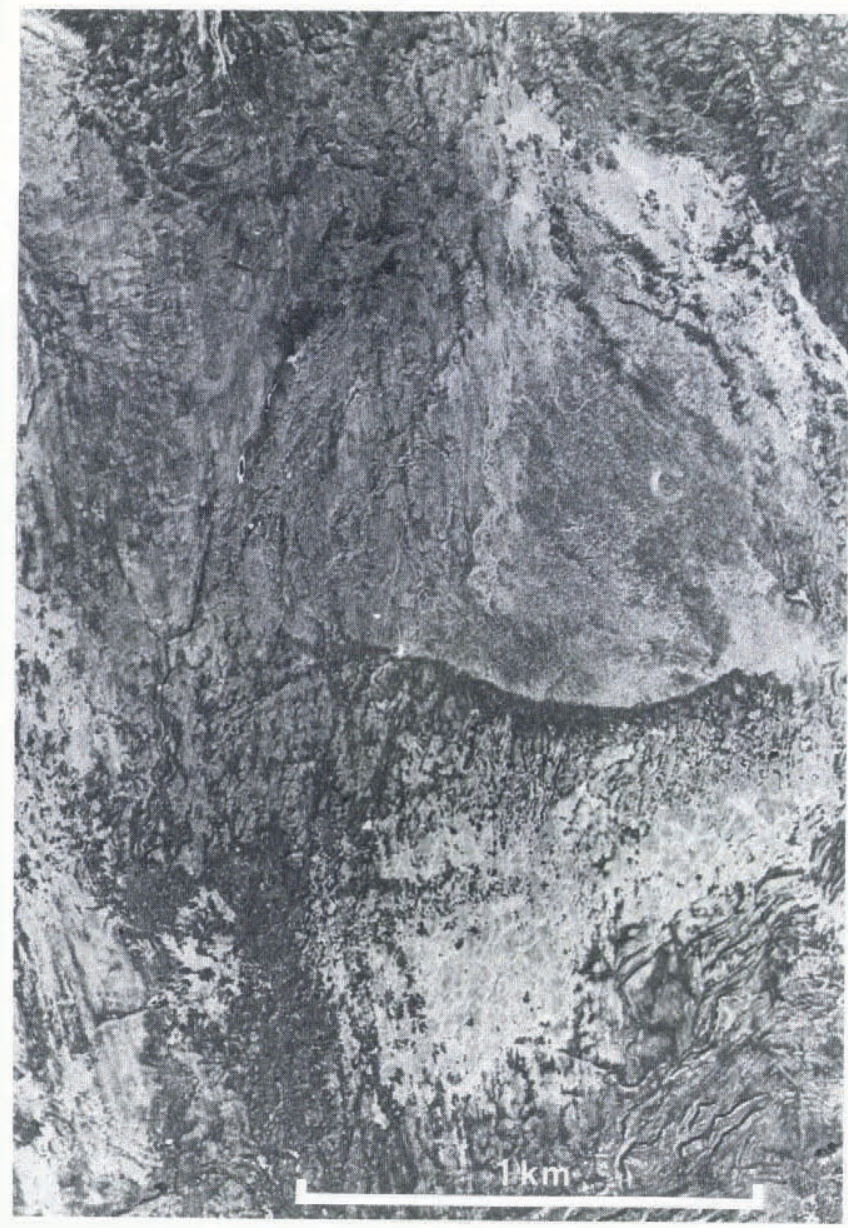

Fig. 6. Vertical aerial photograph of the eastern summit of Häggingfjället. The relict surface $(C)$ is truncated by $a$ cross-mountain till scarp.

bedrock shows a few striations but no developed roche moutonnée shapes. This may be an indication that sustained wet-based ice flow did not occur immediately down-glacier from the scarp. A few hundred metres down-glacier from the bedrock area the ground is completely covered by a $0.5 \mathrm{~km}^{2}$ boulder blanket. As there is no other large bedrock exposure for some kilometres in the up-glacier direction, we infer that the boulders were transported only a short distance. The boulder blanket has tails drawn out in the direction of the fluting. Neither on the sloping till scarp nor on the western summit have any significant sorting phenomena developed since the last glacial event.

\section{Fulufjället}

In contrast to Arvestuottar and Häggingfjället, a preserved periglacial landscape dominates the Fulufjället plateau (Figs 7 and 8). Fluting and other evidence of ice flow are restricted to a corridor (A) aligned along-flow and to "holes" (B and E) in the old patterned-ground surface. Deglacial ice flow over the plateau was from the north-northwest. The down-glacier end of patch B comprises a low crescentic boulder ridge $(\mathrm{C})$ with minor crests transverse to ice flow. At the up-glacier end of patch $\mathrm{B}$ there is a shallow depression with ridges separating numerous small lake and tarn basins. Such basins are absent in the undisturbed relict surface surrounding patch

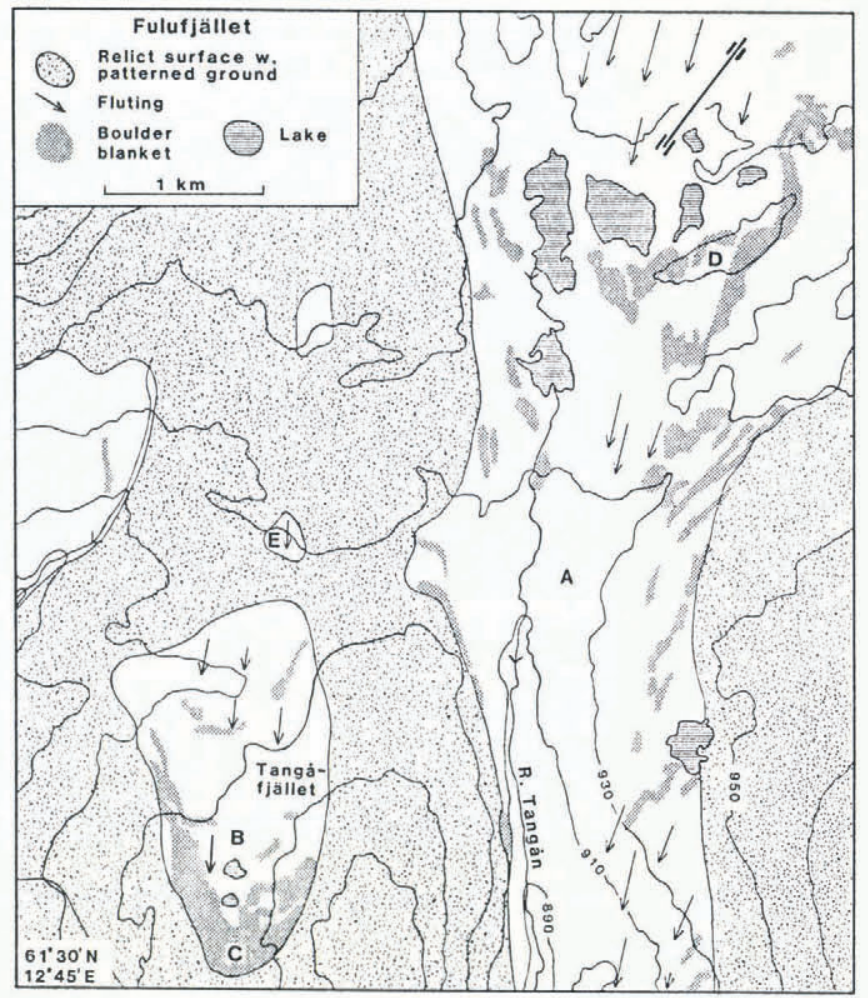

Fig. 7. Map of the relict surfaces and sliding-bed zones $(A, B, E)$ at Fulufjället. The down-glacier end of the fully enclosed sliding patch $(B)$ is marked by an arctuate boulder ridge $(C)$. The arcuate ridge $(D)$ is interpreted to have an origin similar to $(C)$ but has later been subjected to basal sliding and partial destruction.

B. We find it probable that the pre-existing soil cover was extended and fractured in this part of the patch. By visual estimate, the volume of material in ridge $\mathrm{C}$ matches the volume of the depression at the up-glacier end of the patch. It therefore appears that no material was added to or removed from the patch during the late Weichselian stadial. Patch B may represent only short-lived warmbased conditions.

The River Tangån fluted-till corridor (Fig. 7) follows a shallow valley characterized by glacially transported boulder blankets and fluting, but lacking the periglacial features that are present immediately to the east and west (Fig. 9). The corridor is displaced from the valley axis such that the western side follows the valley bottom but the eastern side is much higher. As at Arvestuottar, the flutings show slight convergence towards the sliding zone. The arcuate till and boulder ridge at Tangsjöarna (D, Fig. 7) may be a modified stoss-side moraine, as at Arvestuottar (E, Fig. 3), that was later over-run and partly destroyed when the sliding patches expanded in size.

\section{THE "FROZEN PATCH" LAND-FORM ASSEMBLAGE}

The relict surfaces described here are windows in which periglacial features are preserved, framed by larger expanses of glacial erosion. Somewhat similar windows described elsewhere may reveal old glacial landscapes 


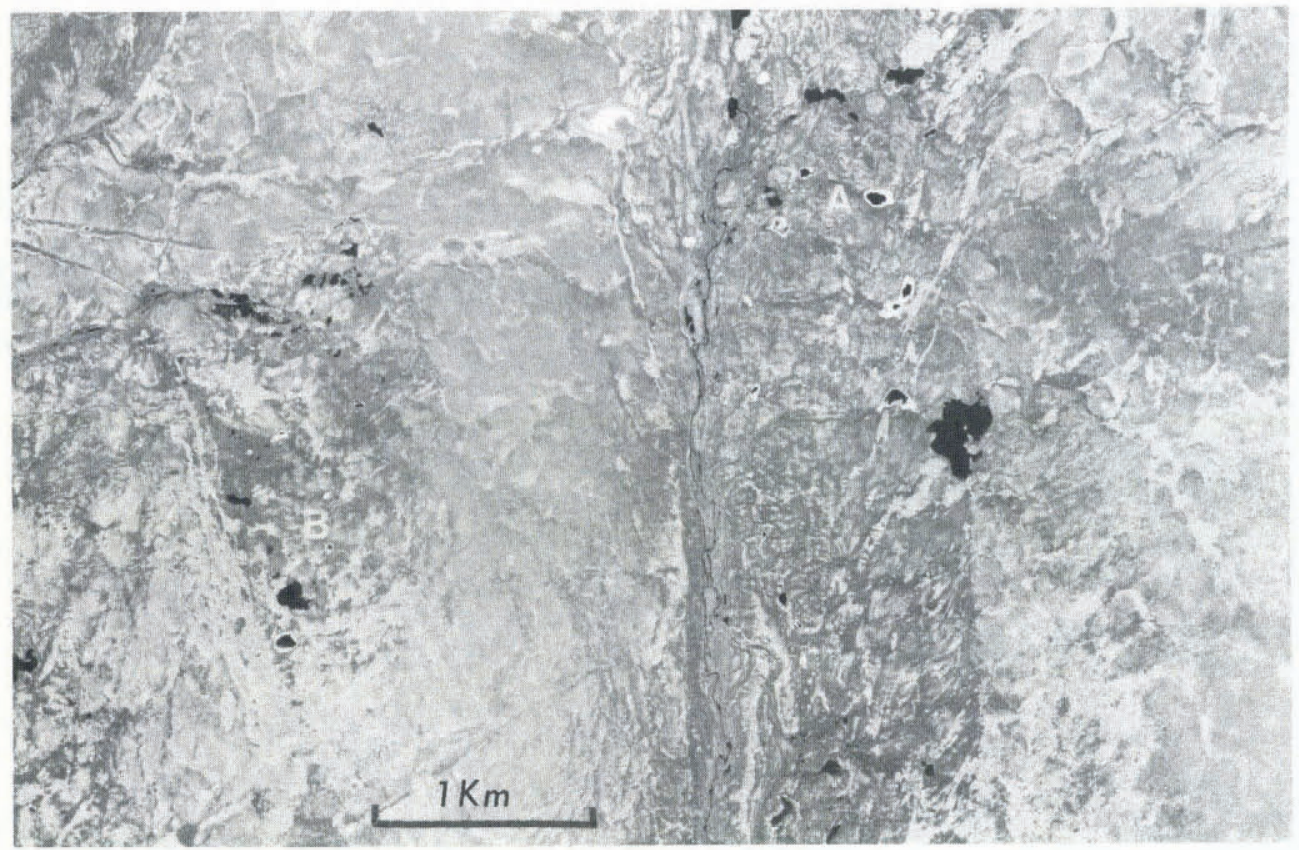

Fig. 8. Vertical aerial photograph of the Tangåfjället and R. Tangån sliding zones, Fulufjället. See Figure 7 for interpretation.

surrounded by younger landscapes with differently oriented flow lineaments (Dyke and Morris, 1988; Lagerbäck and Robertsson, 1988).

In the eastern part of the Scandinavian mountain range, such relict surfaces are characterized by one or more of the following features: large sorted polygons, stable felsenmeers, ventifacts, deeply weathered bedrock and tors. Glacial lineations are generally absent but meltwater channels cut through many of the relict surfaces. In some areas, the channels reflect two or more deglaciations (Rodhe, 1988; Kleman, 1992). In all probability, these surfaces received their last subaerial imprint during an early Weichselian interstadial (Tärendö interstadial; Lagerbäck, 1988a). Theoretically, debris may have been transported englacially across relict surfaces but, except for scattered boulders

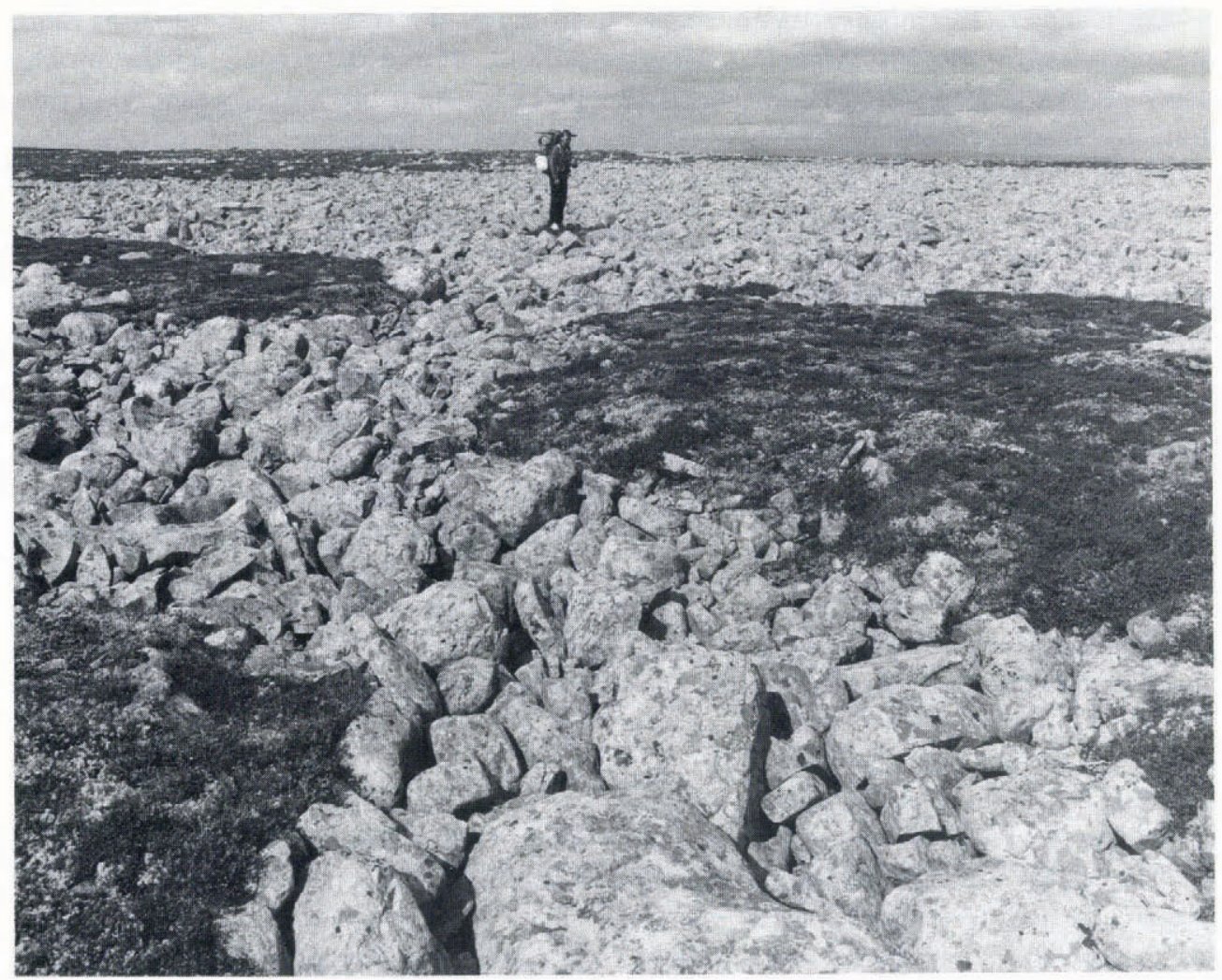

Fig. 9. Relict surfaces at Fulufjället. These surfaces are characterized by boulder depressions and large sorted polygons. Such features are lacking in adjacent areas showing evidence of basal sliding. 


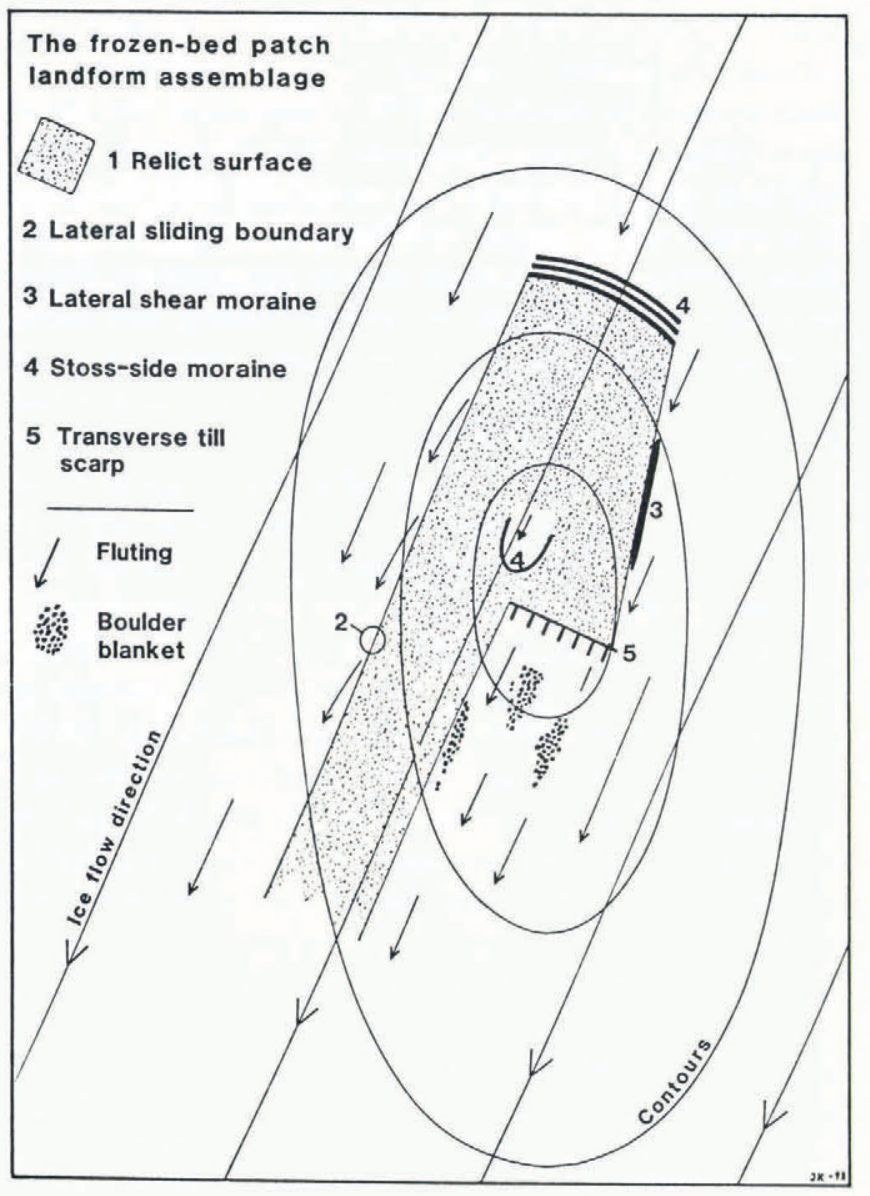

Fig. 10. Five land forms characteristic of the frozen-bed patch environment shown on an idealized mountain. The four thermal boundary land forms are shown in the relative positions in which we have repeatedly identified them.

perched on the otherwise monotonously flat periglacial surfaces, there is little evidence for any significant meltout during the final deglaciation.

The relict surfaces, including the features characteristic of these surfaces, and the four types of thermalboundary land forms described from Arvestuottar, Häggingfjället and Fulufjället (Fig. 10, features 2-5) constitute what we call "the frozen-patch land-form assemblage". We consider these land forms to be important tracers for patchy bed conditions.

To summarize, the four thermal boundary land forms are:

Lateral sliding boundary. A sharp boundary or a narrow transition, laterally separating a zone of subglacial lineations from a truncated relict surface.

Lateral shear moraine. A ridge parallel or sub-parallel to a flow line between a glacially lineated and a relict surface.

Stoss-side moraine. A transverse single- or multi-crested moraine ridge near the proximal edge of a relict surface.

Transverse lee-side till scarp. A scarp in till, oriented transversely to ice flow, separating a proximal relict surface from a distal scoured or otherwise glacially modified surface.
Note that, although boulder blankets are often found at the edges of relict surfaces, they are not unique to that environment, in contrast to the other forms, and are therefore not included in the "frozen-patch land-form assemblage".

\section{THERMAL PATTERNS IN THE BASAL ENVIRONMENT}

The four boundary land forms described above are found only at the edges of former frozen-bed patches. The origin of these land forms is therefore discussed in the light of the three-dimensional thermal distribution in the basal icesoil-bedrock environment. Previous work (Kleman, 1990, 1992), and our interpretation of the regional ice-sheet evolution described below, indicates that the frozen patches are remnants of larger continuous frozen-bed zones. That is, basal temperatures were rising but the pressure-melting point was not reached everywhere before deglaciation.

In terms of land-form development in a subglacial shear field, the interactions of three surfaces and one layer are considered important. These are:

1. The ice/soil contact.

2. The soil/bedrock contact.

3. The soil layer.

4. The phase-change (water/ice) surface, here called the PCS. This surface separates thawed regions from overlying frozen regions. It exerts an important control on the strength of subglacial material and thereby subglacial land-form development. The PCS approximates an isotherm but is not strictly so, as the melting temperature depends on pressure and solute content.

Here we use a simplistic, binary, "strength" classification, in which the strength across the ice/soil and the soil/bedrock contacts is considered to be high if the contacts are frozen but low if they are thawed (Hughes, 1973). Detachment is expected to occur at the PCS, because it separates strong materials from weak ones. The location of the PCS within the substrata, as well as the flow regime (compressive/extending flow) will determine the type of morphological traces that result. As we move downwards from the ice into the substrata, the following relationships are expected:

If the PCS is located at the ice/soil contact, detachment will occur, resulting in basal sliding. Fluting is the expected morphological expression.

If the PCS is located within the soil or at the soil/ bedrock interface, detachment may occur. Detachment at these levels will lead to entrainment and downglacier movement of debris sheets. The morphological expression will depend on the down-glacier fate of these sheets. If they are deposited, stacked one upon another, then positive, mostly transverse land forms are to be expected. If debris sheets are moved downglacier, they normally will be stretched, thinned and dispersed.

If the PCS is located in strong bedrock, no detachment is likely to occur. Ice flow is then achieved only by ice deformation and hence this situation leaves no traces. 


\section{ORIGIN OF LAND FORMS}

Figure 11 shows the PCS intersecting the slopes of a hill. At the summit, the PCS is located well down in strong bedrock. Over topographically lower areas, the PCS is located at the ice/soil contact and basal melting, as well as sliding, occurs.

The transverse till scarps identified previously (numbering around 15) are all located on the down-glacier sides of hill crests, with relict surfaces or land forms preserved upglacier from the scarp. Down-glacier from the frozen-bed patch, the PCS passes through the soil cover, creating a zone where soil frozen to the moving glacier sole overlies thawed soil. As strong material is then forced to move on weak material, detachment is likely to occur. Debris sheets are then entrained in a zone of extending flow. The till scarps indicate that the full soil thickness was removed immediately adjacent to places where nothing was removed. We think that event-like entrainment of the full soil thickness (at the scarp) is the most probable process. Thus, the till scarp is likely to mark the intersection between the PCS and the soil/bedrock contact. In the extending-flow zone, dispersal and thinning of the debris sheet will occur, possibly leaving the scarp as the main trace of the debris entrainment. In this context, it can be noted that Hutter and Olunloyo (1981) pointed out transition lines between frozen and thawed bed as sites of extreme stress concentrations.

Stoss-side ridges are located in the zone up-glacier from the frozen patch, where the PCS also separates an upper layer frozen to the glacier from a lower thawed layer. Detachment is likely to occur here, and in the compressive-flow regime shortening by stacking and/or folding of debris sheets, and thereby creation of positive land forms, is to be expected. Boulton (1972) discussed the possible entrainment of subglacial material at "feathering edges" of subglacial permafrost and attributed importance to possible high subglacial water pressures. Moran and others (1980) described multicrested ice-thrust land forms from the Prairie region in
North America. They attributed them to stacking at a thawed/frozen-bed transition near a cold-based ice margin and, like Boulton (1972), emphasized the role of high subglacial water pressures. The formation of an englacial debris structure at a warm/cold base transition in a small valley glacier was described by Clarke and Blake (1991), who discussed several mechanisms (bulge formation in substratum, recumbent folding and thrust faulting) by which internal layers of basal sediments could form at such a basal transition. As the internal structure of the stoss-side ridges is unknown, we cannot at present be more precise than to state that they appear to be related to folding or thrusting of subglacial sediment in compressive-flow zones up-glacier of frozen-bed patches.

The lateral-sliding boundaries are the most frequent elements delineating frozen-bed patches (or sliding "holes" as at Fulufjället). Deformation of pre-existing features (figs 9 and 10 in Kleman and Borgström (1990)) is direct evidence for strong shearing across such boundaries. We see a frozen/thawed bed boundary as the only reasonable explanation for such strong lateral shearing at the glacier bed. When, due to warming, the PCS rose and intersected the terrain, the former continuous terrain-conformable zone of strong shear, which would be present in the lower part of a fully cold-based ice sheet, was disrupted and sub-vertical shear zones developed close to the base at the sides of frozen patches. The development of an easy-glide fabric by crystal re-orientation in these vertical shear zones may be a mechanism whereby the locations of the lateral sides of sliding zones were self-stabilizing. The fact that lateralsliding boundaries occasionally cut across the topographic grain, as at the Tjuolma site (Kleman, 1992), is a strong indication that properties in the ice govern the lateral location of the sliding zone. If the frozen-patch size is large relative to the ice thickness, then such shear zones can be expected to extend to the ice surface.

The lateral-shear moraines are features that may or may not be present at the lateral-sliding boundaries. The only examples of this feature yet known are the $0.6 \mathrm{~km}$ long

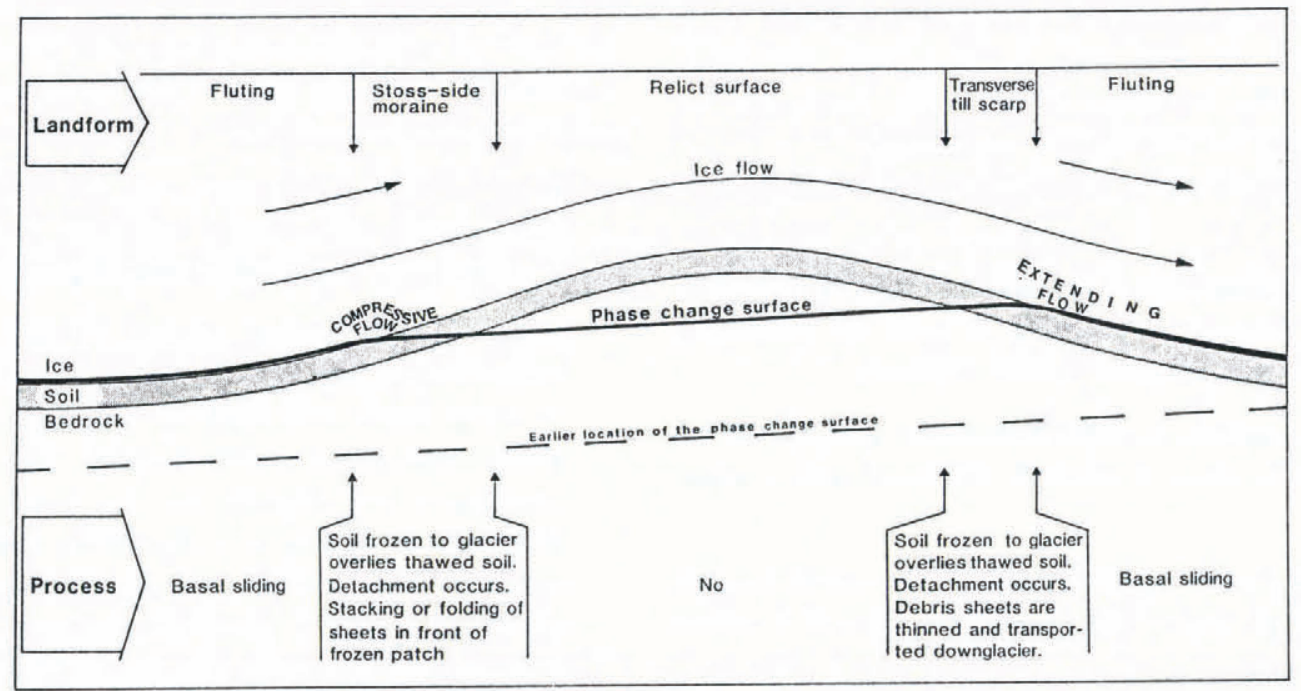

Fig. 11. This shows how a phase-change surface (PCS), that rises over time, creates two detachment zones where soil frozen to the glacier base overlies thawed soil or the soill/rock interface. The stoss-side ridges are thought to have formed by folding or stacking of debris sheets in front of frozen-bed patches, while the transverse till scarps mark the sites where debris sheets were entrained in an extending flow zone. 
Arvestuottar ridge and the $68 \mathrm{~km}$ long ridge described by Dyke and Morris (1988) and Dyke and others (1992) from Prince of Wales Island, Arctic Canada. The Prince of Wales Island ridge appears to be strictly parallel to flow lines. The Arvestuottar ridge, however, is located on a part of the sliding boundary where flutings indicate flow at a small angle $\left(3-5^{\circ}\right)$ into the frozen patch. It can therefore be seen as an extreme case of an oblique stossend ridge, formed by highly skewed folding or thrusting in a compressive environment.

\section{DISCUSSION}

We interpret the relict surfaces to have been subjected to uninterrupted frozen-bed conditions on the patches. Any time period of basal melting at these sites during the 20-50 ka life of the last ice sheet would, in all probability, have erased or buried delicate, relict land forms such as sorted polygons. Where a readily discernible relict landscape is lacking, identification of former frozen-bed patches will be difficult or impossible.

The thermal boundary forms described here separate "young" (last flow stage) forms from relict surfaces. Naturally, thermal boundary forms can also be relict. That is, they can separate two fossil landscapes of different ages. The lateral shear moraine described by Dyke and others (1992) separates two drumlin landscapes of different ages, with the late-glacial flow direction marked by a third, cross-cutting, flow-trace fan. Similarly, a transverse till scarp in the Transtrand mountains was excavated by Kleman and others (1992). The scarp was formed in a lower till unit and overlain by a uniformly thick late Weichselian basal till. Despite draping by a later till, this transverse-till scarp is still a prominent morphological feature.

The three areas we have described here (Figs 3, 5 and 7) indicate a basal-thermal patchiness on the $1-10 \mathrm{~km}$ scale, with the location of frozen-bed zones governed mainly by the location of humps (individual mountains or large hills). Although the mapped areas are too small for any far-reaching conclusions, there appears to be a roughly $1: 1$ relationship between humps and frozen patches. Using the terminology of Hughes (1992), the Arvesuottar and Häggingfjället hill summits were "sticky frozen spots in a slippery thawed matrix", while the Tangån and Tangåfjället patches were "slippery thawed spots in a sticky frozen matrix". The three areas give direct geomorphological evidence that the patchy thermal conditions postulated by Hughes (1981, 1992) have existed under parts of a large ice sheet.

\section{Geographical distribution of relict surfaces and regional basal conditions}

We have identified about 20 well-defined, enclosed patches in medium-relief terrain, of which five are described in some detail here. However, relict land forms (tors, old meltwater channels and old felsenmeers) on interfluves between glacial troughs and less welldelineated relict surfaces are more common than the welldefined patches presented here. Most relict surfaces are located in a zone along the eastern flank of the
Scandinavian mountains, in the northern part adjacent (Kleman, 1992) to the "Veiki" landscape described and dated by Lagerbäck (1988b). This landscape marks a very large (more than $50000 \mathrm{~km}^{2}$ ) area of frozen-bed conditions.

The frozen-bed patches described are unlikely to have been stable features. They are instead interpreted as representing shrinking remnants of once continuous frozen-bed zones that in the north encompassed the eastern part of the mountains (Kleman, 1992) as well as all north-central Sweden. The conclusion that northern Sweden must have had regional frozen-bed conditions during the LGM and earlier flow phases of the late Weichselian is based on the fact that the dated early Weichselian landscape (Lagerbäck and Robertsson, 1988) in north-central Sweden bears no flow traces from the time when the ice divide was centred over the Gulf of Bothnia. The alternative explanation, a LGM ice divide situated over the mountains northwest of Arvestuottar, can be excluded on the basis of the isostatic uplift pattern, the northward-trending Pajala drumlin fan (Kleman, 1990) and the extremely asymmetric ice sheet that would result. A core area of frozen bed in the southern part of the mountain chain is also indicated by relict surfaces and land forms (Sollid and Sörbel, 1988; Kleman and Borgström, 1990; Kleman and others, 1992) but its extent is as yet unknown.

The changing-flow configuration of the ice sheet during the post-LGM stages (Kleman, 1992) gives some clues to the age of the patchy conditions at the Arvestuottar site. Ice flow during the LGM was westward from the main dome over the Gulf of Bothnia. During the decay phase, the ice divide migrated westward, over Arvestuottar, to a final position within the mountain range. The ice flow from the northnorthwest at Arvestuottar is therefore linked to the decay phase (about 11-9 ka), and is unlikely to have lasted more than 1-2 ka, possibly even less. The migration of the ice divide across the site towards the west suggests accelerating flow (as the ice divide moved away to the west) and increased release of deformation energy. Thinning and surface melting could also be responsible for some basal warming.

\section{Consequences for paleo-ice-sheet models}

Hitherto, there has been a consensus that striae, flutings and drumlins are positive evidence for a thawed bed but there has not been a similar consensus about criteria for discerning frozen-bed conditions. We suggest that the relict surfaces are considered positive evidence for frozenbed conditions. We further suggest that the presence of thermal boundary forms, such as those described above, is taken as positive evidence for patchy thermal conditions during at least one interval of a glacial.

Models that calculate ice-sheet temperatures (Hooke, 1977) can therefore be tested against reconstructions of bed conditions based on geological evidence. Timedependent numerical ice-sheet models that require specification of either a sliding condition or a no-slip condition at every point of the bed (Fastook and Holmlund, 1994) can be improved by taking evidence for basal thermal conditions into account. At present, 
good input data are restricted to topography, while other input data are generally deduced through climatological arguments and broad assumptions regarding regional basal conditions and ice viscosity.

Relict surfaces that preserve evidence for existence of frozen-bed conditions can be expected to have been largely destroyed in inward-migrating thawed zones during deglaciation (Kleman, 1992). Therefore, interpretations based on maps of relict surfaces may substantially underestimate the extent of frozen bed that existed during earlier flow phases, and sensible extrapolations will have to be done.

\section{CONCLUSIONS}

Glacially truncated ice-overriden relict surfaces occur along the eastern margin of the Scandinavian mountains. They mark patches of former frozen bed during late stages of the last glaciation. These patches were shrinking remnants of larger frozen-bed zones in west-central and northern Sweden.

The proximal ends of frozen-bed patches are centred on hills but the sides cut across slopes along flow lines.

A distinct land-form assemblage at the edges of frozenbed patches includes stoss-side moraines, lateral-sliding boundaries, lateral-shear moraines and transverse till scarps.

The formation of stoss-side moraines and transverse-till scarps occurs in two detachment zones where soil frozen to the glacier overlies thawed soil. The detachment zones are located where, due to warming, a rising phase-change surface (water/ice) intersects the soil layer up- and downglacier from residual frozen-bed patches.

Identification of relict surfaces and land forms related to patchy basal thermal conditions can improve ice-sheet models by providing more realistic estimates of the extent of sliding.

\section{ACKNOWLEDGEMENTS}

This study was financed through grants from the Swedish Natural Science Research Council. We thank R. LeB. Hooke, N. Iverson, A. S. Dyke, B. Strömberg, S. Jonsson and C. Hättestrand for constructive comments on the manuscript.

\section{REFERENCES}

Andersen, B. G. and J. Mangerud. 1989. The last interglacial-glacial cycle in Scandinavia. Quaternary International, 3-4, 21-29.

Borgström, I. 1989. Terrängformerna och den glaciala utvecklingen i de södra fjällen. Stockholm University. Department of Physical Geography. Meddelande 234.

Boulton, G. S. 1972. The role of thermal régime in glacial sedimentation. In Price, R.J. and D. E. Sugden, comps. Polar geomorphology. London, Institute of British Geographers, 1-19. (Special Publication 4.)

Carol, H. 1947. The formation of roches moutonnées. F. Glaciol., 1(2), 57-59.

Clarke, G. K.C. and E.W. Blake. 1991. Geometric and thermal evolution of a surge-type glacier in its quiescent state: Trapridge Glacier, Yukon Territory, Canada, 1969-89. F. Glaciol., 37(125), 158-169.
Denton, G. H. and T.J. Hughes. 1981. The last great ice sheets. New York, etc., John Wiley and Sons.

Dyke, A.S. 1983. Quaternary geology of Somerset Island, District of Franklin. Geol. Surv. Can. Mem. 404.

Dyke, A. S. and T.F. Morris. 1988. Drumlin fields, dispersal trains, and ice streams in Arctic Canada. Can. Geogr., 32(1), 86-90.

Dyke, A.S., T.F. Morris, D.E. C. Green and J. England. 1992. Quaternary geology of Prince of Wales Island, Arctic Canada. Geol. Surv. Can. Mem. 433.

Fastook, J.L. and P. Holmlund. 1994. A glaciological model of the Younger Dryas event in Scandinavia. F. Glaciol., 40(134), 125-131.

Goodman, D.J., G. C.P. King, D. H. M. Millar and G. de Q Robin. 1979. Pressure-melting effects in basal ice of temperate glaciers: laboratory studies and field observations under Glacier d'Argentière. 7. Glaciol., 23(89) ), 259-271.

Hooke, R. LeB. 1977. Basal temperatures in polar ice sheets: a qualitative review. Quat Res., 7(1), 1-13.

Hughes, T. 1973. Glacial permafrost and Pleistocene ice ages. In North American Contribution. Permafrost. Second International Conference, 13-28 July 1973, rakutsk, U.S.S.R. Washington, DC, National Academy of Sciences, 213-223.

Hughes, T.J. 1981. Numerical reconstruction of paleo-ice sheets. In Denton, G. H. and T.J. Hughes, eds. The last great ice sheets. New York, etc., John Wiley and Sons, 221-261.

Hughes, T.J. 1992. Abrupt climatic change related to unstable ice-sheet dynamics: towards a new paradigm. Palaeogeogr. Palaeoclimatol. Palaeoecol. (Global and Planetary Change Section), 97, 203-234.

Hutter, K. and V. O. S. Olunloyo. 1981. Basal stress concentrations due to abrupt changes in boundary conditions: a cause for high till concentration at the bottom of a glacier. Ann. Glaciol., 2, 29-33.

Kleman, J. 1990. On the use of glacial striae for reconstruction of paleoice sheet flow patterns - with application to the Scandinavian ice sheet. Geogr. Ann., 72A(3-4), 217-236.

Kleman, J. 1992. The palimpsest glacial landscape in northwestern Sweden - Late Weichselian deglaciation landforms and traces of older west-centered ice sheets. Geogr. Ann., 74A(4), 305-325.

Kleman, J. and I. Borgström. 1990. The boulder fields of Mt. Fulufjället, west-central Sweden - Late Weichselian boulder blankets and interstadial periglacial phenomena. Geogr. Ann., 72A(1), 63-78.

Kleman, J., I. Borgström, A. -M. Robertsson and M. Lilliesköld. 1992. Morphology and stratigraphy from several deglaciations in the Transtrand mountains, western Sweden. Fournal of Quaternary Science, 7, 1-17.

Lagerbäck, R. 1988a. Periglacial phenomena in the wooded areas of northern Sweden - relicts from the Tärendö interstadial. Boreas, 17(4), 487-499.

Lagerbäck, R. 1988b. The Veiki moraines in northern Sweden widespread evidence of an Early Weichselian deglaciation. Boreas, $17(4), 463-486$.

Lagerbäck, R. and A.M. Robertsson. 1988. Kettle holes - stratigraphical archives for Weichselian geology and palaeoenvironment in northernmost Sweden. Boreas, 17(4), 439-468.

Lundqvist, J. 1992. Glacial stratigraphy in Sweden. In Kauranne, K., ed. Glacial stratigraphy, engineering geology and earth construction. Geol. Surv. Finl., Spec. Pap. 15, 43-59.

Moran, S. R., L. Clayton, R.LeB. Hooke, M. M. Fenton and L.D. Andriashek. 1980. Glacier-bed landforms of the prairie region of North America. F. Glaciol., 25(93), 457-476.

Prest, V.K., D. R. Grant and V.N. Rampton. 1968. Glacial map of Canada. Ottawa, Geological Survey of Canada. (Map 1253A.)

Rodhe, L. 1988. Glaciofluvial channels formed prior to the last deglaciation: examples from Swedish Lapland. Boreas, 17(4), 511-516.

Sollid, J.L. and K. Kristiansen. 1982. Hedmark Fylke, kvartergeologi og geomorfologi $1: 250$ 000. Oslo, Oslo Universitet. Geografisk Institutt.

Sollid, J. L. and L. Sörbel. 1988. Utbredelsemönstret av glacialgeologiske former i Sör-Norge i lys av breens temperaturforhold. In 18 Nordiske Geologiske Vintermöde, Köbenhavn. Abstracts, 378-379.

Sugden, D.E. 1978. Glacial erosion by the Laurentide ice sheet. f. Glaciol., 20 (83), 367-391.

Sugden, D. E. and S. H. Watts. 1977. Tors, felsenmeer, and glaciation in northern Cumberland Peninsula, Baffin Island. Can. F. Earth Sci., 14(12), 2817-2823.

The accuracy of references in the text and in this list is the responsibility of the authors, to whom queries should be addressed. 